This item was submitted to Loughborough's Research Repository by the author.

Items in Figshare are protected by copyright, with all rights reserved, unless otherwise indicated.

\title{
Trust, distrust and security: An untrustworthy immigrant in a trusting community
}

PLEASE CITE THE PUBLISHED VERSION

https://doi.org/10.1111/pops.12613

PUBLISHER

Wiley

VERSION

AM (Accepted Manuscript)

\section{PUBLISHER STATEMENT}

This is the peer reviewed version of the following article: BILGIC, A., HOOGENSEN GJORV, G. and WILCOCK, C., 2019. Trust, distrust and security: An untrustworthy immigrant in a trusting community. Political Psychology, 40 (6), pp.1283-1296, which has been published in final form at https://doi.org/10.1111/pops.12613. This article may be used for non-commercial purposes in accordance with Wiley Terms and Conditions for Use of Self-Archived Versions.

\section{LICENCE}

CC BY-NC-ND 4.0

\section{REPOSITORY RECORD}

Bilgic, Ali, Gunhild Hoogensen Gjorv, and Cathy Wilcock. 2019. "Trust, Distrust and Security: An Untrustworthy Immigrant in a Trusting Community”. figshare. https://hdl.handle.net/2134/38098. 
Accepted Version 17.06.2019

Political Psychology

\title{
Trust, Distrust and Security: An Untrustworthy Immigrant in a Trusting Community
}

In security studies, there is an unquestioned assumption of a linear link between trust and security. However, such assumption neglects complex identity dynamics that can be involved in trustbuilding discourses for engendering security. This article contributes to the literature on trust, security, and identity in International Relations (IR) by making a case for a conceptual focus on the formation of particularized distrust towards "the other" as a corollary to trust and security of "the self". It is argued that in the construction of a political community where security is associated with trust, particularized distrust can also be promoted through institutional discourses strengthening the "trusting we" by constructing "the other" who can challenge social trust and feelings of security associated with it. The argument is illustrated through critically examining a state level narrative in Norway in relation to "the other", that is, immigrant. Through this illustrative example, mutual constitutiveness of trust and distrust in a self/other discursive construction will be shown.

\author{
Ali Bilgic, Loughborough University \\ Gunhild Gjorv Hoogensen, the Arctic University of Norway \\ Cathy Wilcock, the Institute of Social Studies, the Hague
}


Trust between states and within societies has been shown to create a sense of security by constructing common social norms and collective identities, exemplified in the literature on security dilemmas (Booth and Wheeler, 2008; Bilgic, 2013), conflict resolution (Keating and Ruzicka, 2014), regional security (Exner-Pirot and Murrey, 2017; Heininen, 2019), and human security (UNOCHA, 2009). Simultaneous to trust's security-enhancing role, there can be a "dark side of trust" (Skinner, Dietz and Weibel, 2014) whereby particular constructions of a trust relationship also generate "distrust" towards certain people or groups (see also, Tilly, 2005). This demonstrates that trust and distrust relationships can intricately be bound with the formation of self-other relationships. In other words, the recognition of the "trusting self" can actively entail the construction of the "distrustful other". This analysis will make a case for the importance of conceptualizing and studying "particularized distrust" in the exploration of the relationship between security and trust and asks: how is security stemming from particularized trust based on a collective identity engendered in relation to "the other" who is constructed as the object of particularized distrust?

In security studies, there needs to be greater examination into what is meant by trust, and upon what, and whom, how the politics of identity works in social trust building, and how states can influence this process. Although trust-building is an affective process and related to feelings of (in)security, this emotional aspect has almost always been neglected in security studies. By addressing these gaps in trust and identity conceptualizations in security studies, it will be argued that in the construction of a political community where security is associated with trust, particularized distrust can also be promoted through a state level narrative- strengthening the "trusting we" in relation to the "other", who can challenge trust and feelings of security associated with it. The argument will be illustrated through critically examining discursive examples of social 
trust building at the state level in Norway. It will be demonstrated how a state-level narrative on "the self" can move the community away from "the other" through normalization of "homogeneity" as a condition of social trust in Norway.

The first conceptual section starts with the discussion of how trust has been studied in relation to identity in security studies literature. Against this backdrop, trust and, in particular social trust as the main focus of the analysis, will be defined. This is followed by the conceptualization of particularized distrust as an affective phenomenon that can constructs "the other" as opposed to the trusting/trustworthy self, whose security is challenged by the presence of the latter. The conceptual section ends with the examination of why the role of state actors that have the privilege of formation and communication of political discourses can be problematized to study the nexus of particularized distrust-identity-security. Having made the aforementioned points in the first conceptual section, the second section of the article articulates an illustrative example of a mutually constitutive interaction between trust and distrust in relation to the self/other formation. The investigation draws on the state level narrative on immigration and social trust in the Norwegian context - a country credited with having some of the highest levels of social trust in the world (Andreasson, 2017; Calmfors, 2014; ESS, 2016) but also where immigration has been claimed to challenge the prevalence of social trust (Andreasson, 2017; Eriksen, 2014).

"It is through narrativity that we come to know, understand, and make sense of the social world, and it is through narratives and narrativity that we constitute our social identities" (Somer, 1994, p. 606). Focusing on the identity formation process through discourse, the main method to be employed in the empirical section is narrative analysis. IR scholars have focused on state narratives through which state level actors make sense of what/who the state and political community are and how they are related to "the other" (Steele, 2008; Delehanty and Steele, 2009; 
Subotic, 2016). (Auto)biographical narratives create a story line about the state or nation that connects its history with its present but also gives directions regarding its future. In other words, they are essentially normative (Wertsh, 2000, p. 518). "They carry a desire for a particular social order and a particular set of social practices and policies" (Subotic, 2016, p. 612). In their normative outlook in the narration of "the self", "the other" can be identified historically and externally as well as in relation to contemporary internal "others" (Delehanty and Steele, 2009, p. 524). By comparing and contrasting with "the other", narratives provide positive self-image, a continuity, particularly in times of crises, that aims to restore or maintain ontological security (Kinnvall, 2006; Mitzel, 2006; Steele, 2008; Eberle and Daniel, in this issue; Adisonmez, in this issue). As Kinnvall argues (2004, p. 755), narratives offer "comforting stories [about the Self] in times of increased ontological insecurity and existential anxiety". In other words, they can discursively construct feelings of security.

The analysis will primarily focus on Norwegian White Papers on immigration. Through these documents, it will be discussed how "the self" is narrated in relation to trust and how "the other" is situated in this narrative about the trusting allegedly "homogenous" self. In particular, it will be demonstrated the ways in which the immigrant's otherness is constructed as an object that can challenge social trust and from which the "homogenous self" can be moved away affectively. As a result, it will be demonstrated how the narrative of trusting self as a source of feeling of security can concomitantly build distrust towards "the other" as a source of feelings of insecurity. These illustrative examples explore the possible ways in which distrust, as promoted through a state level narrative, raises questions about the linear assumptions regarding the relationship between trust and security, specifically examining the ways that state actors use notions of "homogeneity" to frame discourses of dis/trust. With this illustration, it is not the analytical 
intention to draw generalisable conclusions from Norway by stating that the narrative studied is exclusive and not contested. Rather, the discussion's objective is to illustrate the conceptual utility of our approach to trust.

\section{Conceptualising Particularized Distrust as an "Emotional Belief"}

The relationship between security and identity has long been a subject of contestation in security studies (Williams, 1998). A stream of studies identifies the construction of the threatening and dangerous other as an integral part of the politics of security (Campbell, 1992; Schafer, 1999; Neocleous, 2008). Another group of scholars have adopted a different perspective arguing that the self/other dichotomy is not necessarily violent and exclusionary (Hansen, 2012); the dichotomy can be socially deconstructed (McSweeney, 1999) and even a common identity can be constructed (Adler, 1997). With the "affective turn" in IR, the role of emotions in (de)constructions of self/other relations has increasingly been under investigation (Hutchison, 2010 and 2016; Åhäll and Gregory, 2013). It has been argued that positive and negative emotions can be collective; they are represented in discourses and performances of various political actors and through their representations, collective identities are (de)constructed. In these studies, "the other" is often the object of negative emotions of the self, such as fear, anxiety, hate, and disgust (Ahmed, 2004, pp. 62-101; Kinnvall, 2018; Bilgic, 2018). Trust has been examined as a tool of building common security and identity (Adler, 1997; Booth and Wheeler, 2008; Keating and Ruzicka, 2014; Kegley and Raymond, 1990; Pouliot, 2010), though affective aspects of trust and their important role in identity construction have been overlooked. 
One of the most significant conceptual works in the area of security, identity and trust, to the date, is Booth and Wheeler's security dilemma theorization (2008). They argue that in order to transcend a security dilemma, fear between states can be replaced with trust although trust between states would not be enough to transcend a security dilemma and trust should be embedded in intersocietal relations. In embedded trust, trust is so internalized in social relations that it is not possible to talk about separate identities and different interests: two "I"s become one "we" (Booth and Wheeler, 2008, pp. 230-233). Booth and Wheeler's trust conceptualization hints at the importance of institutions, particularly state actors, in building social trust to address insecurity. However, it not only fails to conceptualize how a common identity construction can be enacted emotionally, therefore overlooking an affective dimension of dis/trust (see below), but also assumes a straightforward link between trust and security by obscuring "the darker side of trust". In Trust and Rule (2005, pp. 1-4), Charles Tilly argues that trust can become an important boundary marker between an in-group and out-group and that threat perception towards the culturally (religiously, in his example) determined group increases in-group trust, and therefore distrust towards the outsiders. As will be discussed in the second section, the literature on social trust in the area of migration resonate with this point.

A more nuanced understanding between trust, security and identity, which is cognizant of the politics of identity and security, is required. As this is an affective process, which is almost always neglected in trust literature in security studies, understanding the role of emotions in identity construction processes can help to develop such a nuanced approach. How states can influence in-group and out-group boundaries affectively through (dis)trust-building narratives of "the self" can be questioned in this context. In the following, trust, and in particular, social trust 
will be discussed. This discussion will lead to the conceptualization of particularized distrust as an affective phenomenon.

According to Hosking (2017, p. 10), trust refers to "(a) attachment to a person, collective of persons or institution, based on the well-founded but not certain expectation that he/she/they will act for my/our good and (b) the expectation, based on good but less than perfect evidence, that events will turn out in a way not harmful to me/us". The current discussion focuses on trust towards collective of persons, that is, social trust which "refers to the level of confidence people have in the moral orientation or trustworthiness of their fellow citizens" (Li, Smith, and Dangerfield 2018, p. 174). There are three main approaches that explains why people develop this attachment and expectation. According to the rationalist approach, which was adopted within security studies debates in IR (eg. Kydd, 2005), trust originates from the "rational assessment of another's goodwill and reliability in a risk exchange situation" (Ring and Van de Ven, 1994, see also Hardin, 2004). To counter the rational approach, secondly, it is argued that calculative trust is a contradiction in terms because understanding trust as "calculated risk" has "completely removed the ideational nature of trust that might make it a distinct social phenomenon" (Keating and Ruzicka, 2014, p. 758; see also Karpik, 2014; Möllering, 2014). Trust, after all, is a “feeling” (Hosking, 2017, p. 10). It is based on positive expectations and attachments, which are not only calculable but also affective (see also, Capelos and Wheeler et al., in this issue).

By combining these two approaches, a third position arises. As Dietz (2011, p. 215) argues, "there is always an assessment (however thorough) of the other party's trustworthiness" in the trust-building process. O'Neill (2002) and Holton (1994) consider trust to be a "belief responsive to evidence" (Radoilska, 2014, p. 120). In this midway model, people do "not [trust] blindly as small children, but with good judgement" (O'Neill, 2002, p. 141). Misztal (1996, p. 22) states that 
through trust, "human beings, as emotional, rational and instrumentally oriented agents, [seek] to ensure that their social relations and arrangements meet their emotional, cognitive and instrumental needs". Individuals choose to trust not blindly, but based on calculation of evidence and past experiences, and they decide to trust according to their interests (Holton, 1994, Radoilska, 2014). However, the willingness to trust can stem from affect as well as cognition. As Mercer (2010, p. 6) states, "[t]rust based on feelings of warmth and affection allows one to go beyond the incentives or evidence and to risk being wrong" and identifying trust as "emotional belief" (see also Hosking, 2017, p. 10). In the study of social trust, this discussion adopts the third position as trust cannot be reduced to either rational calculations or emotional affinities but a combination of both (Hosking, 2017).

Social trust is divided into generalized trust and particularized trust. Eric Uslaner (2002) and Delhey, Newton and Welzel (2011) understand "generalized trust" as a way to accept people who may be perceived as unfamiliar (e.g. "strangers") as nevertheless members of an expanded moral community and defines them as receivers of trust. Khodyakov (2007) calls this "thin interpersonal trust" stemming from expectations that others will act fairly, honestly, and honourably by virtue of their membership to a moral community. Generalized trust has a vision of a moral community as wide as possible including "strangers" who are not known or who are socioculturally or ethnically “different” from "the self”. In contrast, Uslaner (2002) and Yamagashi and Yamagishi (1994) investigate "particularized trust", or the feeling of trust directed towards the members of a specifically defined group. "The central idea distinguishing generalized from particularistic trust is how inclusive your moral community is" (Uslaner, 2002, p. 27). The latter is similar to what Khodyakov (2007) calls "thick (or dyadic) interpersonal trust" based on familiarity and similarity. 
Social trust is constructed on the basis of different communal identity articulations. Generalized trust, on the one hand, assumes an inclusive identity within a moral community and all who enter into it (Crepaz, 2007). Particularized trust, on the other hand, restricts the scope of trust to a narrower group based on more specific identity markers such as shared ethnicity, nationality, religious affiliations and so on. It reflects an active and positive response to assumptions of likeness or a collective bond based on a specific identity. When particularized (thick or dyadic) trust is high, it can be detrimental to constructing a relationship based on generalized trust. This is one of the points that the discussions on trust-identity relation in security studies have overlooked. In security studies, trust has been praised as a way to pursue security by constructing a common identity. However, this common identity construction process can be conducted as opposed to "the other" who is depicted as a threat/risk/challenge to the trusting "self". To put it differently, the type of trust often articulated in security studies is not generalized but particularized trust. This discussion examines how particularized trust as an instrument of collective identity construction and promises "comforting stories" to the members of this collective identity, can also work as constitutive of "particularized distrust".

Distrust can be identified as "unwillingness to make one self's vulnerable" in relation to another (Dimoka, 2010, p. 367). Marsh and Dibben argue that distrust has an active role whereby people choose to not trust and must therefore "adopt a negative strategy" of not trusting (Marsh and Dibben, 2005, p. 18). This choice can be rooted in a lack of information or evidence, resulting in an active decision not to trust (ibid). It identifies the lack of positive expectations and attachments towards another. However, there is also an affective dimension of distrust. Mercer (2010, p. 15) calls this “feelings of pessimism in another's good will and competence", related to the availability and interpretation of evidence. Rephrasing Mercer's "trust as emotional belief", it 
is the absence of warmth and affection. Distrust concerns "expectations of things feared" (Lewicki et al, 1998, p. 439). Although fear and distrust should not be conflated, there can be a close relationship between the two. Lack of warmth and affection in distrust can feed fear and anxiety (Sharfstein, 2015, see also Solomon and Flores, 2001; Sztompka, 1999). On these bases the question of what trust and distrust affectively do in the generation of security in a common identity construction process arises.

Sara Ahmed (2004) provides useful tools to understand how trust and distrust are constructed and reconstructed through identities and emotions. She argues that the movement of emotions - between inside and outside, embodying the contact and histories of contact between the subject and object (the "other" who is the target of emotion) - create affective responses of othering, which is central to processes of trust/distrust. Emotions have a role in formulating power relations - both in producing the subject who feels and enacts emotions as well as the object who is the target of the subject's emotions. With each contact between subject and object previous impressions are still active, while new impressions are made. Repeated negative associations with the object works to reproduce and essentialize the object as "the other" and as lesser or hateful. When subjects enact, or perform, their emotions, they move towards or away from the object and in this way, emotions have a boundary-producing effect. Following this line of thinking, while trust affectively moves "the self" towards "the other", and therefore, creates the possibility of constructing a common we-feeling, distrust moves "the self" away from "the other". Particularized distrust involves cognitive and emotional determinants that reproduce certain groups as the untrustworthy objects.

Discourse is one of the fundamental planes where emotions are represented and communicated, and therefore, constitutive to the self/other construction processes (Hutchison and 
Bleiker, 2014; Hutchison, 2016). The discussion aims to pay attention to the role of states in construction of particularized social distrust through their narratives. As studies in political psychology indicate, state actors are important to increase social trust (Dinesen and Jaegar, 2013; You, 2012). Without trust, cooperation and sense of belonging are impaired (Anderson, 2010) and, therefore, is the very existence of community. State-level actors, through their discourses and regulations, engage actively in increasing trust as instruments of producing a political community that functions and flourishes. Their practices can engender a discursive context where individuals who allegedly share certain characteristics are expected to move towards each other through trusting performance. However, as critical security scholarship demonstrates (Bigo, 2002; Campbell, 1992; Huysmans, 2006), and underlining the boundary marking problem of trust Tilly points out, this common identity construction process can be, albeit not necessarily, conducted through defining "others" who are repeatedly produced as sources of insecurity to the imagined political community: producing them as fearsome objects. The current analysis adds that these "others" can be produced as objects that can challenge social trust, so the community (its members) are expected to move away from them. In this way, moving towards "the self" and moving away from "the other" interact in the state level narrative of community building, producing certain "different" groups as threats to the imagined homogeneous political community.

This conceptual discussion has so far articulated that the relationship between trust, identity, and security is more complex that assumed in security studies. Firstly, trust and distrust are not necessarily in binary positions in the politics of security but particularized distrust can be constitutive to trust and security associated with it. While particularized trust affectively brings the community together, particularized distrust moves the community away from "the other". Secondly, institutions, such as state actors, can be influential in the process of constructing and 
moving the collective trusting community away from the "other". In the following section we take illustrative examples from Norwegian state-level sources with the intent to raise questions about general claims about high levels of social trust in Norway.

\section{Trust, Immigration and Security}

The objective of this analysis is to problematize the almost always presumed link between trust and security by illustrating how security through trust-building can sometimes be constitutive to distrust and insecurity towards "the other". The conceptual and empirical focus on the construction of particularized distrust can also advance the ongoing discussion in critical security studies on the migration-security nexus. Critical security studies focusing on migration have argued that fear, anxiety and unease are fundamental affective dynamics that permeate both the public imagination and discourse about immigration, but also technologies of governmentality (Burke, 2008; Huysmans, 2006; Bilgic, 2013; Lazaridis, 2016, Lianos, 2016). They show that while migration cannot be associated with any measurable decline in "objective" security, in many contexts, migration has adversely affected the overall sense of "subjective" security (Miller, 1998, Bigo, 2002). It means that although migration does not present "a clear and present danger" to security in any objectifiable verified way, "threat" is felt and it is emotionally registered (Massumi, 2015, p.18). This feeling of insecurity towards immigrants is often discursively (re)produced (Wodak, 2015).

The relationship between social trust and migration can have implications for feelings of (in)security. However, there is no consensus on how this relationship plays out in different social contexts. For example, Herreros and Criado (2009) argue that high levels of social trust renders 
societies more inclusive of immigration. In this case, social trust is understood as generalized trust to "strangers". Furthermore, Hooghe, Reeskens, Stolle and Trappers (2009) as well as Zimdars and Tampubolon (2012) could not find a negative correlation between ethnic diversity and social trust in European societies. On the contrary, Delhey and Newton (2005) and Van der Meer and Tolsma (2011) argue that in ethno-culturally (heterogeneous) diverse societies social trust is low, and therefore, immigration would be an obstacle to building trust as social capital. In this respect they do not refer to generalized trust but to thick or particularized trust whereby a trust relationship is directed towards ingroup and distrust towards outgroup. This "darker side of trust" emerges in contexts of ordinarily high particularized social trust where there is a correlating high particularized distrust reserved for immigrant populations. This means that high social trust cannot be understood as "generalized", as previously thought, but rather as a particularized form of trust for an in-group into which the "immigrant other" is not given access. The empirical studies that find out the negative correlation between social trust and immigration are often based on the "group threat theory", which refers that "feelings of outgroup fear, prejudice and [d]istrust" are engendered while ingroup solidarity and cohesion is maintained (Kokkonen et. al., 2014; see also Dinesen and Sonderskov, 2013). Feelings of insecurity towards the outgroup accompany feelings of security within the group where particularized trust is high.

As Radoilska (2014) argues, such particularized distrust in cultural "others" is generally not attributable to a cognitive assessment of evidence but to an affective and intuitive belief which is refutable with evidence. It represents a "Cassandra problem" whereby a "misjudged refusal to trust" persists "even where there is adequate if inevitably imperfect evidence of trustworthiness" (O'Neill 2002, p. 141). Therefore, an analysis that solely focuses on the cognitive dimension of social trust cannot explain why immigrant populations are often, albeit not always, left out of the 
social trust enjoyed among host populations, and therefore excluded from "the self". Through understanding the affective basis of distrust that moves "the self" away from "the other" can we understand how felt insecurity is constructed discursively and how it persists in immigration contexts. If the relationship between dis/trust and security is to be fully understood in the context of migration, dis/trust can be articulated as an "emotional belief" and the role of state actors' discourses in producing it can be questioned. Next, the claims made about trust in Norway will be unpacked by raising questions about such claims of trust in relation to how trust and distrust have been framed in these examples and to demonstrate how these dual constructions work.

\section{Norwegian Social Trust?}

How do states tell "comforting stories" about "the trusting self" and how do these stories concomitantly construct "the other" who can challenge the feelings of security stemming from trust? The following discussion draws on the example of Norway for two reasons. Firstly, survey data, which is also often applied to Nordic societies in general, demonstrates that Norway has high levels of social trust (SSB 2016; ESS 2016; Andreassen 2017). Secondly, the Nordic states in general have a long history with both in- and out-migration. Up until the 1980s the Nordic states have had many similarities in their experiences with migration, mostly with people moving between Nordic countries and thereafter with and beyond the European Economic Area/European Union (Pettersen \& Østby 2013). Since then, however, migration patterns have become differentiated between the Nordics, as have migration policies. Norway's immigration politics have been characterised as a type of middle-road between the stricter and less inclusive policies of the Denmark, and the more liberal migration politics of Sweden (ibid). Statistically, $17 \%$ of the Norwegian population has an immigrant background. Of the ten largest immigrant groups in 
Norway, the majority were from EU/EEA countries at 53\% (Poland, Lithuania, Sweden, Germany), where the remaining $46 \%$ come from Somalia, Pakistan, Iraq, Syria, Eritrea, and the Philippines (SSB 2018).

To provide an illustration of how the immigration and trust discourse have developed in Norwegian state level narrative, this analysis highlights representations of the debate from two White Papers: "Velferd og migrasjon: Den norske modellens framtid (Welfare and Migration: The Future of the Norwegian Model)" (NOU, 2011) and "Integrasjon og tillit: Langsiktige konsekvenser av høy innvandring (Integration and Trust: Long term consequences of high immigration)" (NOU, 2017). The White Papers serve both as a source of information and advice but are also performative moves by the government demonstrating its commitment to address any challenges stemming from migration, and to maintain social trust within the political community. Examples from these reports can illustrate state level narrative of the trusting self in interaction with the other.

The 2011 White Paper focuses on the effects of immigration on the Norwegian welfare model. The report notes that in "international comparisons Norway ranks high when it comes to trust ... this trust is a necessary ingredient for the continuation of the welfare state model" (NOU, 2011: 21). It further claims that "this trust has been decisive in Norway in creating the foundation for the welfare state, and trust has been maintained by the institutions of the welfare state" (ibid). It is further claimed that "culture, structures of trust, and effective welfare institutions have been closely bound together in the creation of the welfare model" (ibid: 22). In the narrative on positive self-image, trust is articulated as instrumental to the creation and maintenance of an important social structure upon which Norway's population contributes to as well as relies upon. 
The 2011 White Paper notes the extent to which Norway, home to people from well over 200 different countries, has established itself as a multicultural, immigration-based country. At the same time however, the report refers frequently to the "relatively homogenous" (e.g. 2011: 61) society in which the Norwegian welfare model has been developed. It claims that the "most comprehensive welfare states are found in countries that are relatively ethnically homogenous" (NOU 2011: 307), and that this "high level of ethnic homogeneity and strong welfare states in the Nordic region are not at all coincidental" (ibid). This point is addressed directly regarding immigration and a sense or feeling of belonging ("samhørighet") to the society (ibid: 306). In turn, heterogeneity in society is raised as a problematic issue in relation to the maintenance of trust (ibid: 304). This White Paper places the weight of its focus on the importance of socio-economic conditions in Norway, and how to maintain these conditions by maintaining high level of trust within the society.

What is interesting, however, is how immigration enters the discussion. Central to the discussion is the experience of belonging to the greater community: "a belonging that can be based on ethnic or national similarity or other criteria" (ibid: 306$)$. The connection one has to "the nation" is argued to have a particularly important role, and the commitment to the welfare state is based on "an understanding that members of a given group have a natural or inherent skepticism to members of other groups" (ibid: 307, italics added). The "natural" or "inherent" connection to people of the same group, is further linked to nation-building and the development of the nation as a community (ibid). As stated further "If the impression of the national community must be given up as a result of immigration and increased diversity, the welfare state may well falter" (ibid: 307). The White Paper refers to work by Alesina and Glaeser (2004) who claim that "immigration from poorer countries, which have given Europe a large group of poor people who are of darker 
skin than the majority, will open the way for racist demagogues who connect racist assumptions to welfare goods" (ibid: 308). The narrative of the report suggests that homogeneity provides a feeling of security- not least when the feelings of belonging engendered within homogenous groups are naturally occurring processes. In other words, the nation is connected to an understanding of sameness or similarity between members of that community, and the othering of those considered outside of this community is natural. This sameness within the nation is instrumental to the success of the welfare state, which is intrinsically connected to high trust levels in Norway.

In parallel, the report's narrative creates a hierarchy of class between the immigrant groups in relation to their "contributions" to the society and welfare state. It makes a distinction between refugees and those with high levels of education and qualifications, who are more easily integrated into the Norwegian welfare system as they immediately contribute to the workplace and society at large. "The increasing number of refugees and family immigrants with limited qualifications demonstrated a clear structural tension in a qualification-demanding Norwegian labour market with high salaries" (ibid: 13). People immigrating from the EEA are identified as those who are able to quickly integrate into Norwegian society and contributing to the welfare system due to their high qualifications whereas people with low qualifications pose a potential problem to similar capacities to integrate and to support the welfare state model (ibid). Following the logic of the explicit linkages made between trust, culture (homogeneity) and the welfare state (see above), the narrative implies that those who are less able to contribute to the welfare model would become a problem for the welfare system and Norwegian society as a whole.

The 2011 White Paper is not explicit when it comes to identifying who would potentially weakens the existing welfare system, but more generally identifies them as those who are 
"immigrants who have obtained residency on humanitarian grounds who have low qualifications or who have difficulties to document their qualifications" (ibid: 51). The origins of immigrants came into more significant focus in the 2017 White Paper, where again, those with lower education and qualifications are highlighted as potentially having a more difficult time integrating and contributing to Norwegian society, but also where a greater focus was placed on one particular group, that of Muslims.

The 2017 White Paper examines the capacities of the Norwegian welfare state to include immigrants, particularly those with "low qualifications" (NOU 2017: 11). However, contrary to the 2011 White Paper, the 2017 report opens with concerns about refugees stating that "[the] extensive influx of asylum seekers and refugees during the summer and fall of 2015 put the Norwegian immigration system under dire pressure. The number of asylum seekers was the highest ever and the scope of international refugee crises in multiple, simultaneously occurring conflicts indicated that the pressure would continue" (ibid). The 2017 White Paper directly evaluates the possibilities of integration of specific peoples from outside of the EU/EEA region with their impact on Norwegian social trust levels, examining the "conditions needed to maintain unity and trust in the Norwegian society" (ibid: 12).

The 2017 White Paper follows a similar logic with the 2011 White Paper when it claims early on that "Norway has historically been ethnically and culturally a relatively homogeneous country" (NOU, 2017, p. 12), though it recognizes that the "the country has experienced immigration since Norway took its form as a state in the 900s" (ibid: 162). Indeed, it goes so far as to ask: "Is national identity and national/ethnic homogeneity for example a basic condition to recreate a society's way of life?" (ibid: 166). It reflects concerns pertaining to cultural differences 
between asylum-seekers/refugees and Norwegian society including a focus on childrearing, schooling, and gender equality.

Norway has historically been a relatively homogenous country ethnically and culturally. Equality and equal treatment have been important premises for support and legitimacy in Norwegian politics after the central welfare institutions were put in place. Equality as a social fact and a normative ideal can be challenging for persons with backgrounds from other cultures. At the same time, parts of the majority population might become concerned that the ideals of equality will crumble due to the society becoming more heterogeneous (ibid: 12).

Homogeneity is not explicitly defined beyond the qualifying term "ethnic", but in contrast to the White Paper of 2011, Muslim groups - either directly or implicitly - are addressed in the 2017 White Paper. It notes that the dominant or majority population "has a significant responsibility for ensuring that trust-building with immigrant communities will be successful. Examples of radicalisation in Muslim communities are a de facto sign of a failure of trust towards the Norwegian society amongst certain groups" (ibid: 17). Muslims are also explicitly addressed when it comes to problems of exclusion and discrimination in Norwegian society, for example referencing research that looked at the tendencies for Norwegian workplaces to discriminate against people with "typical Muslim/Pakistani names" in comparison to people with typical Norwegian names, noting levels of discrimination in both the capital city of Oslo (where discrimination rates were higher) as well as in the rest of Norway (ibid: 133). The White Paper notes that "approximately half of the Norwegian population is skeptical to Muslims, and 60\% were negative to having a Muslim son or daughter-in-law. This is significantly more than those who demonstrate skepticism towards other religions" (ibid: 169). The paper illustrates various ways in which differences between Norwegian culture and Islamic cultures are used to generate scepticism and particularised distrust against Muslims. 
The role of Islam in contrast to "other religions" in daily life is also addressed, referring to a form of "Muslim exceptionalism, or rather the hypothesis that there is a characteristic about Islam that makes Muslims virtually immune to the secularisation process that has influenced Europe" (ibid: 172). The 2017 White Paper relies heavily on various studies that monitors relations between non-immigrant Norwegians and Muslims. It is not all negative, and for example, both nonimmigrant, secular/Christian youth, and Muslim (first and second generation immigrant) youth appear to have generally tolerant views about each other, and more similar attitudes towards religion in Norwegian society (such as accepting marriage outside of one's religion) (ibid: 173). However, many cultural differences are highlighted including regarding gender equality and childrearing, as well as towards the tendency to become radicalised, not just amongst minorities such as Muslims, but also far-right extremist groups in response to Muslim immigration (p. 177).

According to the White Paper, Norwegian social trust relying upon a sense of equality is challenged if immigrants:

experience discrimination, [and] if they experience that the institutions in the country they have come to treats them arbitrarily and badly, and if they are not allowed the room to live as they choose. For the majority trust is undermined if they experience immigrants contribute too little to the community, and that there arises a strong tendency towards segregation into enclaves characterised by attitudes and practices the majority considers to be unacceptable" (ibid: 161).

Trust, in the Norwegian case, is explicitly framed in such a way that it depends on the negotiations between an assumed homogenous majority and "the other". Generalised trust become contingent upon the nature of particularised distrust, the latter of which has the potential to dissipate insofar as "the other" conforms to what the majority considers to be acceptable.

As discussed with reference to Ahmed (2004), repeated negative associations with the object reproduce and essentialise the other. The positioning of the claim of the homogenous dominant culture and its values (equality) directly against the claim about "the other" as not sharing 
these important cultural values, sets up a negative association or feeling to specific "outside" groups. Throughout the 2017 White Paper, the challenges of integration and cultural harmony with specifically Muslim peoples and communities are raised, reinforcing a sense of concern, if not fear (one section of the report focuses on radicalisation and terror) associated with a particular group on the basis of primarily cultural racism.

As argued by Kristin Loftsdóttir and Lars Jensen (2012), Nordic country narratives can assume a hegemonic whiteness - which often translate to "homogeneous" insofar as whiteness characterises Nordic national identities despite the longstanding presence of "other" identities, not least indigenous. As noted in the brief examples above, however, more often than not, homogeneity is not explicitly defined, though it is implied through the positioning of claims, the use of "ethnic" to distinguish peoples, and even the use of the small numbers of indigenous peoples as a defense of the homogeneous claim. In the 2017 White Paper, the "us" and the "other" are racialised, where "we" become not only Norway but in general the EU/EEA that is the receiving end of asylum seekers/refugees who are arriving from outside of the EU/EEA - in particular, Muslims. Although "whiteness" is rarely articulated as an identity, "ethnic Norwegian/Swedish/Danish/Finnish is a more common characterization. As argued by Iqbal and Todi (2015), assumptions of homogeneity inform dominant perceptions of Nordic societies. Because of the lack of direct articulation of "whiteness" as the prevailing majority identity, it is difficult to explicitly illustrate exactly what is meant by these authors as "homogeneous". This is not surprising however, as the normalised ethic and racial identity does not need explicit expression. It is "known" or taken for granted.

The discourse of "homogeneity" in the narrative operates on a process of particularised trust, which in turn can be detrimental to generalised trust (see discussion in theory section above). 
However, this is problematic in relation to the self/other constructions and how trust works affectively. Homogeneity is an identity marker of sameness, which generates a sense of feeling of belonging for some, and exclusion for others. The assumption of sameness is strong in the narrative articulated in the White Papers This does not mean that Norway does not have a culturally and/or ethnically diverse population. Nor does it mean that the Norwegian society would be negatively impacted by increasing diversity. The White Papers do not make such claims. However, the narrative of "the self" in the documents that normalises the term "homogeneity" or "homogeneous" can create or reinforce feelings of particularised distrust towards those who are not assumedly included. Particularised trust in those who are considered "the same" quickly relies on a simultaneous particularised distrust against those who are framed as "the other". In other words, security stemming from particularised trust is constitutive to insecurity towards immigrant and distrust particularly targeting this image. Through particularized distrust, the trusting Norwegian community whose homogeneity is constructed through state discourses on trust is moved away from "the other".

\section{Conclusion}

The discussion has problematized the almost-natural association between trust and security by unpacking the complex identity dynamics in the process of trust-building. This association often risks masking dynamics of distrust-building towards new "others". This is problematic partly because the notions and practices of security and of insecurity can be mutually constitutive. Presenting trust-building as an unquestioned policy of security can be conceptually and politically misleading. A more paramount problem, however, stems from the fact that trust-building as a 
policy of security can disguise insecurity of certain individuals and social groups who are constructed as "untrustworthy others". Therefore, our contribution to theories of trust combined with illustrative examples from Norway that is assumed to exemplify high trust levels, has demonstrated how the construction of trust can be constitutive to distrust towards (a specific) other and demonstrates that insecurity can be an integral dimension of particularized dis/trust as much as security. It has been argued that particularized trust as a source of security can be constitutive to particularized distrust towards "the other", who is racialized, gendered, and classed.

The analysis and conceptualization of particularized distrust has showed the necessity of studying how self/other relations can work in generation of security defined as a common wefeeling, which is often ignored in the trust-identity discussions in security studies. The trustsecurity literature largely operates based on abstracting dis/trusting political actors (whether they are decision-makers, social groups, or civil society actors) from their social and economic contexts. Distrusting as well as trusting individuals and communities cannot be studied as abstractions but subjects and objects. Another conclusion concerns the case of Norway. Our examples show that trust and distrust-building is evident in a state-level narrative and can contribute to the construction of an allegedly homogenous Norwegian identity, which is considered being challanged, by “different" immigrant groups. To what degree do cultural and economic differences, which are learned contextually in Norway, and reinforced by state actors, result in distrust towards a selective group of immigrants among the population? As inside and outside conflate, the "ethnically homogenous" Norwegian community may move away from the object of distrust, that is, the abstract image of the immigrant. However, this "abstract image" in the Norwegian identity imagination is highly racialized and classed, not just at the local level but also by the state. 
The research on trust and identity in security studies has the potential to articulate different notions and practices of security, and therefore, releasing the concept of security from the negative emotions of fear, anxiety, and hate. However, in order to realise this potential, a more nuanced understanding of trust that is conscious of its affective role in identity constructions should be developed. This analysis has shown a way to perform such analysis. Trust conceptualisations in security studies should engender a dialogue with emotions research in IR in general, and research on the role of emotions in security in particular.

\section{References}

Adisonmez, U., in this special issue.

Adler, E., Barnett, M., \& Smith, S. (1998). Security communities. Cambridge: Cambridge University Press.

Åhäll, L. (2018). Affect as methodology: feminism and the politics of emotion. International Political Sociology, 12(1), 36-52. https://doi.org/10.1093/ips/olx024

Åhäll, L., \& Gregory, T. A. (2013). Security, emotions, affect. Critical Studies on Security, 1(1), 117-120. https://doi.org/10.1080/21624887.2013.790217

Ahmed, S. (2004). Collective feelings: or, the impressions left by others. Theory, Culture \& Society. 21, 2, 25-42.

Alesina, A., and Glaeser, E.L. (2004). Fighting poverty in the US and Europe: A world of difference. Oxford: Oxford University Press.

Anderson, M. R. (2010). Community psychology, political efficacy, and trust. Political Psychology, 31, 1, 59-84. https://doi.org/10.1111/j.1467-9221.2009.00734.x

Andreasson, U. (2017). Trust - the Nordic gold. Analysis Report. Copenhagen, Nordic Council of Ministers.

Bækholdt, S. (2012). Fornorskning (Norwegianisation). Oslo, Vega.

Bigo, D. (2002) Security and immigration: Toward a critique of the governmentality of unease. Alternatives: Global, Local, Political 27, 1, 63-92.

Bilgic, A. (2013). Rethinking Security in the Age of Migration: Trust and Emancipation in Europe. London: Routledge.

Bilgic, A. (2018). Migrant encounters with neo-colonial masculinity: producing European sovereignty through emotions. International Feminist Journal of Politics, 20, 4, 542-562.

Booth, K. and Wheeler, N. (2008) The security dilemma: fear, cooperation, and trust. Hampshire: Palgrave Macmillan.

Burke, A. (2008). Fear of security: Australia's invasion anxiety. Cambridge: Cambridge University Press. 
Calmfors, L. (2014). How well is the Nordic model doing? Recent performance and future challenges. In T. Valkonen \& V. Vihriälä (Eds.), The Nordic model - Challenged but capable of reform (pp. 17-90). Copenhagen: Nordic Council of Ministers.

Campbell, D. (1992). Writing security: United States foreign policy and the politics of identity. University of Minnesota Press.

Capelos, T., Wheeler, N. et al. in this issue.

Crepaz, M. (2007). Trust beyond borders: immigration, identity and the welfare state in modern societies. Ann Arbor, MI: University of Michigan Press.

Delehanty, W. K., \& Steele, B. J. (2009). Engaging the narrative in ontological (in) security theory: insights from feminist IR. Cambridge Review of International Affairs, 22(3), 523540.

Delhey, J. Kenneth Newton, (2005) Predicting cross-National levels of social trust: global pattern or Nordic exceptionalism?, European Sociological Review, 21, 4, 311327, https://doi.org/10.1093/esr/jci022

Delhey, J., Newton, K., \& Welzel, C. (2011). How general is trust in most people? Solving the radius of trust problem. American Sociological Review, 76, 5, 786-807. https://doi.org/10.1177/0003122411420817

Dietz, G. (2011). Going back to the source: Why do people trust each other? Journal of Trust Research, 1, 2, 215-222. https://doi.org/10.1080/21515581.2011.603514

Dimoka, A. (2010). What does the brain tell us about trust and distrust? Evidence from a functional neuroimaging study. MIS Quarterly, 373-396.

Dinesen, P. T., \& Jæger, M. M. (2013) The effect of terror on institutional trust: new evidence from the 3/11 Madrid terrorist attack. Political Psychology, 34, 6, 917-926.

Dinesen, P. T. \& Sonderskov, K. M. (2013). Ethnic diversity and social trust: the role of exposure in the micro-context. Paper presented at the Ethnic Diversity and Social Capital conference, Berlin, 24-25 May.

Eberle, J. and Daniel, J., in this issue.

Eriksen, T. H. (2014). Who or what to blame: Competing interpretations of the Norwegian terrorist attack. European Journal of Sociology 55, 2, 275-294.

ESS (2016). Attitudes towards Immigration and their antecedents: topline results from round 7 of the European Social Survey. London, European Social Survey ERIC.

Exner-Pirot, H., \& Murray, R. W. (2017). Regional order in the Arctic: negotiated exceptionalism. Politik, 20, 3. https://doi.org/10.7146/politik.v20i3.97153

Hansen, L. (2012). Reconstructing desecuritization: the normative-political in the Copenhagen School and directions for how to apply it. Review of International Studies, 38, 3, 525-546.

Hardin, R. (2002) Trust and trustworthiness. New York: Russell Sage Foundation.

Heininen, L. (2019). Special features of Arctic geopolitics - a potential asset for world politics. In M. Finger \& L. Heininen (Eds.), The Global Arctic Handbook (pp. 215-234). https://doi.org/10.1007/978-3-319-91995-9_13

Hemmings, C. (2012). Affective solidarity: Feminist reflexivity and political transformation. Feminist Theory, 13, 2, 147-161. https://doi.org/10.1177/1464700112442643

Herreros, F., \& Criado, H. (2009). Social trust, social capital and perceptions of immigration. Political Studies, 57, 2, 337-355. https://doi.org/10.1111/j.1467-9248.2008.00738.x

Holton, R. (1994). Deciding to trust, coming to believe. Australasian Journal of Philosophy, 72, 1, 63-76. https://doi.org/10.1080/00048409412345881 
Hooghe, M., Reeskens, T., Stolle, D., \& Trappers, A. (2009). Ethnic diversity and generalized trust in Europe: a cross-National multilevel study. Comparative Political Studies, 42, 2 , 198-223. https://doi.org/10.1177/0010414008325286

Hosking, G. 2017 'Trust in the trustworthy: a key to social cohesion?' in: report of the expert group" trust at risk? Foresight on the medium-term implications for European Research and Innovation Policies (TRUSTFORESIGHT)" Luxembourg: Publications Office of the European Union. 8-16.

Hutchison, E. (2010). Trauma and the politics of emotions: Constituting identity, security and community after the Bali bombing. International Relations, 24(1), 65-86.

Hutchison, E., \& Bleiker, R. (2014). Theorizing emotions in world politics. International Theory, 6(3), 491-514.

Hutchison, E. (2016). Affective communities in world politics. Cambridge: Cambridge University Press.

Huysmans, J. (2006). The politics of insecurity: Fear, migration and asylum in the EU. London: Routledge.

Iqbal, R., \& Todi, P. (2015). The Nordic model: existence, emergence and sustainability. Procedia Economics and Finance, 30, 336-351. https://doi.org/10.1016/S22125671(15)01301-5

Karpik, L. (2014). Trust: reality or illusion? A critical examination of Williamson. Journal of Trust Research, 4, 1, 22-33. https://doi.org/10.1080/21515581.2014.891318

Keating, V. C., \& Ruzicka, J. (2014) Trusting relationships in international politics: No need to hedge. Review of International Studies, 40, 4, 753-770.

Kegley, C. W., \& Raymond, G. A. (1990). When trust breaks down: Alliance norms and world politics. University of South Carolina Press.

Khodyakov, D. (2007) Trust as a process: A three-dimensional approach, Sociology, 41, 1, 12021.

Kinnvall, C. (2004). Globalization and religious nationalism: Self, identity, and the search for ontological security. Political Psychology, 25(5), 741-767.

Kinnvall, C. (2006). Globalization and Religious Nationalism in India: The Search for Ontological Security. New York: Routledge.

Kinnvall, C. (2018). Ontological insecurities and postcolonial imaginaries: The emotional appeal of populism. Humanity \& Society, 42(4), 523-543.

Kokkonen, A., Esaiasson, P., \& Gilljam, M. (2014). Migration-based ethnic diversity and social trust: a multilevel analysis of how country, neighbourhood and workplace diversity affects social trust in 22 countries. Scandinavian Political Studies, 37, 3, 263-300.

Kydd, A. (2005) Trust and mistrust in international relations. Princeton: Princeton University Press.

Lazaridis, G. (2016). Security, insecurity and migration in Europe. London: Routledge.

Lewicki, R. J., McAllister, D. J., \& Bies, R. J. (1998). Trust and distrust: New relationships and realities. Academy of Management Review, 23, 3, 438-458.

Levi, M., \& Stoker, L. (2000). Political trust and trustworthiness. Annual review of political science, 3, 1, 475-507.

Li, Y., Smith, N. and Dangerfield, P. (2017) Social trust: the impact of social networks and inequality. British Social Attitudes 35: Social Trust The National Centre for Social Research. 
Lianos, M. (Ed.). (2016) Dangerous others, insecure societies: fear and social division. London: Routledge.

Loftsdóttir, K., \& Jensen, L. (2012). Whiteness and postcolonialism in the Nordic region: exceptionalism, migrant others and national identities. London: Routledge.

Marsh, S., \& Dibben, M. R. (2005). Trust, untrust, distrust and mistrust - An exploration of the dark(er) side. In P. Herrmann, V. Issarny, \& S. Shiu (Eds.), Trust Management (Vol. 3477, pp. 17-33). https://doi.org/10.1007/11429760_2

Massumi, B. (2015). The remains of the day. In Linda Ahall and Thomas Gregory (Eds.), Emotions, politics and war (pp. 18-33). London: Routledge.

Mercer, J. (2010). Emotional beliefs. International Organization, 64, 1, 1-31.

McSweeney, B. (1999). Security, identity and interests: a sociology of international relations. Cambridge: Cambridge University Press.

Miller, M. J. (1998). International migration and global security. In Nana Poku and David Graham (Eds.) Redefining security: Population movements and national security, (pp. 1527) London: Praeger.

Misztal, B. (1996) Trust in modern societies: the search for the basis of social order. Cambridge: Polity.

Mitzen, J. (2006) Ontological Security in World Politics: State Identity and the Security Dilemma. European Journal of International Relations, 12, 341-370.

Möllering, G. (2014) Trust, calculativeness, and relationships: A special issue 20 years after Williamson's warning, Journal of Trust Research, 4, 1, 1-21.

Neocleous, M. (2008). Critique of security. Edinburgh: Edinburgh University Press.

Nielsen, B.B. (2011) Trust in strategic alliances: toward a co-evolutionary research model. Journal of Trust Research 1, 2, 159-176.

NOU 2017 Integrasjon og tillit: Langsiktige konsekvenser av høy innvandring. Norges offentilige utredninger NOU 2017:2. Oslo, Departementenes sikkerhets- og serviceorganisasjon/Informasjonsforvaltning.

O’Neill, O. (2002) A Question of trust. Cambridge: Cambridge University Press.

Pettersen, S., and Østby, G. (2013). Innvandrere i Norge, Sverige, og Danmark. Samfunnsspeilet Oslo, Skandinavisk komparativ statistikk om integrering. 5: 76-82.

Pouliot, V. (2010). International security in practice: the politics of NATO-Russia diplomacy. Cambridge: Cambridge University Press.

Radoilska, L. (2014). Immigration, interpersonal trust and national culture. Critical Review of International Social and Political Philosophy, 17, 1, 111-128. https://doi.org/10.1080/13698230.2013.851486

Ring, P. S., \& Van De Ven, A. H. (1994). Developmental processes of cooperative interorganizational relationships. Academy of Management Review, 19, 1, 90-118. https://doi.org/10.5465/amr.1994.9410122009

Schafer, M. (1999) Cooperative and conflictual policy preferences: The effect of identity, security, and image of the other. Political Psychology, 20, 4, 829-844.

Sharfstein, J. M. (2015). On fear, distrust, and ebola. JAMA, 313, 8, 784-784. https://doi.org/10.1001/jama.2015.346

Skinner, D., Dietz, G., \& Weibel, A. (2014). The dark side of trust: When trust becomes a poisoned chalice. Organization, 21, 2, 206-224.

https://doi.org/10.1177/1350508412473866 
Solomon, R. C., \& Flores, F. (2001). Building trust in business, politics, relationships, and life. Oxford: Oxford University Press.

Somers, M. R. (1994). The narrative constitution of identity: A relational and network approach. Theory and society, 23(5), 605-649.

Steele, B. J. (2008) Ontological Security in International Relations: Self-Identity and the IR State. London: Routledge.

Subotić, J. (2016). Narrative, ontological security, and foreign policy change. Foreign policy analysis, 12(4), 610-627.

SSB (2018). Dette er Norge 2018 (This is Norway 2018). Oslo, Statistisk Sentrabyrå (Statistics Norway).

Sztompka, P. (1999) Trust: a sociological theory. Cambridge: Cambridge University Press.

Tilly, C. (2005) Trust and rule. Cambridge: Cambridge University Press.

UNOCHA. (2009). Human security in theory and practice. Retrieved from https://www.unocha.org/sites/dms/HSU/Publications\%20and\%20Products/Human\%20Sec urity\%20Tools/Human\%20Security\%20in\%20Theory\%20and\%20Practice\%20English.pdf

Uslaner, E. M. (2002) The moral foundations of trust. Cambridge: Cambridge University Press.

Van der Meer, T. \& Tolsma, J. (2011). Ethnic diversity and its supposed detrimental effects on social cohesion: a review of 56 empirical studies'. Paper presented at the ECPR general conference, Reykjavik, 26-27 August.

Van Dijk, T. A. (1993). Principles of critical discourse analysis. Discourse \& Society, 4, 2, 249283

Williams, M. (1998). Identity and the politics of security. European Journal of International Relations, 4, 2, 204-225. https://doi.org/10.1177/1354066198004002003

Wodak, R. (2015). The politics of fear: What right-wing populist discourses mean. London: Sage.

Yamagishi, T., \& Yamagishi, M. (1994). Trust and commitment in the United States and Japan. Motivation and Emotion, 18, 2, 129-166.

You, J. S. (2012) Social trust: fairness matters more than homogeneity, Political Psychology, 33, $5,701-721$.

Zimdars, A., \& Tampubolon, G. (2012). Ethnic diversity and European's generalised trust: how inclusive immigration policy can aid a positive association. Sociological Research Online, $17,3,1-11$. 